\title{
OCALIĆ GAJĘ I ZBAWIĆ ZBIOROWOŚĆ. \\ EKOTEOLOGICZNE SUGESTIE BRUNONA LATOURA ${ }^{1}$
}

Ewa Bińczyk

Uniwersytet Mikołaja Kopernika w Toruniu

28 lutego 2013 roku zakończyła się w Edynburgu seria wykładów Brunona Latoura Facing Gaia. A New Inquiry into Natural Religion (Latour 2013). Zostały wygłoszone w ramach prestiżowych Gifford Lectures, które odbywają się w Szkocji regularnie od roku 1888, umożliwiając prezentację poglądów uznanych myślicieli propagujących idee teologii naturalnej. Wystapienia te pokazały, że biblijne słowa dotyczące „odnowienia oblicza Ziemi” rozbrzmieć mogą na nowo w dość intrygujący sposób właśnie w wywodach socjologów zainteresowanych polityczną przyszłością wspó1czesnego świata, takich jak Latour. Zawarte w wykładach postulaty teologii politycznej, geopolityki, argumenty postsekularne czy ekoteologiczne należy jednak odczytywać bardzo uważnie, bowiem łatwo o ich deformację. Sa ulokowane w kontekście pozostałych pojęć i oryginalnych założeń filozoficznych współtwórcy teorii aktora-sieci (ang. Actor-Network Theo$r y$, ANT).

Warto podkreślić, że ANT jest projektem głęboko relacjonistycznym, kwestionującym filozoficzne założenia esencjalizmu. Wywodzi się ona z obszaru naturalistycznie zorientowanych studiów nad nauką oraz technologia (ang. Science and Technology Studies, STS), określanych początkowo również jako socjologia wiedzy naukowej. Jest to stanowisko posthumanistyczne, wpisujące się w „zwrot ku rzeczom” we współczesnej humanistyce, inicjujące także nową postać konstruktywizmu („materialnie” usytuowanego, a nie społecznego). W jaki sposób można w jednym projekcie połączyć wątki teologiczne $\mathrm{z}$ tak konsekwentnie antyesencjalistycznym

\footnotetext{
${ }^{1}$ Autorka dziękuje anonimowym recenzentom za cenne sugestie i uwagi do tekstu.
} 
sposobem myślenia, jakim jest ujęcie Latoura? Jest to ciekawe pytanie, na które postaram się szkicowo odpowiedzieć w prezentowanym tutaj artykule ${ }^{2}$.

\section{/// Charakterystyka naszych czasów: porzucenie antropocentryzmu w epoce antropocenu?}

Temat zbawienia wedle Latoura powinien dotyczyć całości Stworzenia (ang. Creation), dzieła Bożego ujmowanego nie tylko jako przestrzeń zaludniona indywidualnymi duszami ludzkimi, ale także jako terytorium czynników pozaludzkich (ang. non-bumans). Uwarunkowania klimatu, rozmaite gatunki, artefakty, mikroby oraz infrastruktury technologiczne sprzężone są z losem społeczeństw. W XXI wieku nie możemy już arogancko koncentrować się tylko na człowieku. W epoce globalizacji jesteśmy od siebie coraz bardziej zależni. Przyszło nam żyć w świecie hybrydycznych powiązań, niejednorodnych ontologicznie: infrastruktury technologiczne posplatane sa z instytucjami społecznymi, czynnikami określanymi dotąd jako naturalne, rozstrzygnięciami prawnymi i decyzjami o charakterze politycznym. Dzięki sprzęgnięciu ze sobą spektakularnego praktycznego sukcesu laboratoriów, przemysłu, procesów globalizacji i uwarunkowań rynkowych wytworzyliśmy nową formę ryzyka. Ulrich Beck w 1986 roku nazwał je nowoczesnym ryzykiem systemowym: niewidzialnym, ponadpaństwowym i zagrażającym destabilizacją znanego nam świata (ekologiczna, finansową oraz polityczna). Jak zatem podkreśla Latour, ocalić od ryzyka i zbawić należy nie samo społeczeństwo ludzi, lecz zbiorowość (ang. collective) - obszar ludzi i czynników pozaludzkich. Do tego właśnie sprowadza się zawarty w myśli francuskiego badacza program porzucenia modernistycznego antropocentryzmu ${ }^{3}$.

\footnotetext{
${ }^{2}$ Popularność Latoura oraz STS w Polsce stale wzrasta. Pragnę zwrócić uwagę, że czwarta już praca tego autora, Nadzieja Pandory. Eseje o rzeczymistości w studiach nad naukq, ukazuje się właśnie nakładem Wydawnictwa Naukowego UMK (Latour 2012). Na temat nurtu STS i stanowiska Latoura piszę szeroko w swojej książce Technonauka w spoteczeństwie ryzylka. Filozofia wobec niepożqdanych następstw praktycznego sukcesu nauki (Bińczyk 2012).

${ }^{3}$ Warto zaznaczyć, że chociaż wcześniej Latour akceptował kategorię ryzyka Becka, podkreślając podobieństwa między nią i pojęciem heterogenicznego aktora-sieci (Latour 2003: 36), to jednak w wykładach Facing Gaia pojęcie ryzyka zostało skrytykowane. W zamian wystąpiła kategoria zagrożenia (ang. threat). W opinii francuskiego socjologa, używając pojęcia ryzyka, budujemy nieuzasadnione wrażenie kontrolowalności sytuacji, obliczalności. Sugerujemy, że możemy zlokalizować i zdefiniować źródła zagrożeń, oszacować ich skutki i w odpowiedzi podjąć słuszne decyzje polityczne. Dyskurs matematyzacji niebezpieczeństw, a także nurty zarządzania ryzykiem, publiczną percepcją ryzyka czy szacowania ryzyka (ang. Technology Assessment - TA) często w nieuzasadniony sposób zakładają pewną formę mierzalnej i rynkowej przewidywalności. Wpisują się w neoliberalną „logikę” zarządzania stratą. Tymczasem w odniesieniu do współczesnych zagrożeń (głównie ekologicznych) nie mamy komfortu kontroli.
} 
Jednak w 2000 roku, kiedy to można już było obserwować wygodne sytuowanie się humanistyki na pozycjach posthumanistycznych, ekolog Eugene F. Stoermer oraz badacz atmosfery Paul J. Crutzen (jak na złość) zaproponowali określenie obecnej epoki geologicznej mianem ,antropocenu" (Crutzen, Stoermer 2000). Głównym powodem był niebagatelny, obserwowany w wielu obszarach i potwierdzany przez różne dyscypliny przyrodoznawstwa, negatywny wpływ człowieka na planetę: atmosferę, bioróżnorodność, glebę i zasoby wodne.

Znaleźliśmy się niespodziewanie w wyjątkowych, dość paradoksalnych i niespójnych czasach. Porzucenie aroganckiego antropocentryzmu nastapiło dopiero w epoce antropocenu (Latour 2011a: 3). Ciagle rachityczna postać planetarnej wrażliwości ekologicznej zaczęła kiełkować dopiero wtedy, kiedy okazało się, że nie istnieje niezależne od ludzkiego praxis środowisko. Przekształcając na szeroką skalę otoczenie (przez wylesianie, biotechnologię, przemysłowe rolnictwo i hodowlę zwierzat, patentowanie form żywych, wytwarzanie organizmów transgenicznych, przemysłowe połowy ryb i deregulację homeostazy oceanów), wkroczyliśmy w epokę postnaturalna. Nie ma już powrotu do Natury stanowiącej stabilne i dane z góry tło ludzkiego działania. Jesteśmy w sytuacji, w której, po pierwsze, ograniczenia naszej planety stały się wyraźnie odczuwalne, a po drugie, w tak niespotykanym stopniu przyszłość środowiska jest zależna od człowieka. Najbardziej paląca kwestią okazuje się przy tym problem zmiany klimatycznej (globalnego ocieplenia), spowodowanej emisjami gazów cieplarnianych, wytworzonych głównie przez działalność ludzką (przede wszystkim wycinanie lasów, hodowlę zwierząt i spalanie paliw kopalnych w transporcie, energetyce i przemyśle).

Wobec wyzwań ekologicznych antropocenu ani nauki humanistyczne, ani nauki ścisłe nie moga pozostawać dłużej obojętne. Nie tylko geologia i geografia, ale także socjologia i politologia winny ulec pojęciowej i teoretycznej transformacji. Jasne jest również to, że nie powinniśmy kontynuować działań politycznych ograniczonych wymogami dotychczasowych modeli rozwoju (Kiepas 2000: 31). Jak jednak prowadzić namysł teoretyczny oraz politykę w tej paradoksalnej sytuacji? Latour nie po raz pierwszy próbuje odpowiedzieć na to właśnie pytanie (por. Latour 2009). Z cała moca podkreśla, że oświeceniowe nadzieje na to, iż kolejny raz ocali nas mechanizm bussiness as usual, czyli dalszy postęp naukowy i technologiczny, 
są nieuzasadnione ${ }^{4}$. Liczyć na procesy podnoszenia świadomości indywidualnych konsumentów to, podobnie, dosyć utopijna, karkołomna ścieżka.

Może zatem pomoc zaoferuje nam teologia? Skoro paradygmat upartego modernizowania, ciagłej pogoni za rynkowymi nowościami oraz zyskiem w warunkach nowoczesnego ryzyka systemowego zagraża stabilnej przyszłości planety, to być może odnowienie mowy religijnej mogłoby stanowić rzeczywistą szansę polityczną? Zdaniem Latoura byłaby to wartościowa alternatywa, o ile udałoby się ustanowić związki pomiędzy religia a całością Stworzenia, to znaczy zarówno ludźmi, jak i czynnikami pozaludzkimi (zamiast postulowanego dotąd, acz niespełnionego, sojuszu religii z uniwersalizowaną, obiektywizowaną i niedostępną Natura).

\section{/// Udręczenia mowy religijnej}

Przez serie kolejnych procesów odczarowywania świata modernizm dokonał dekompozycji sfery religijności. Zredukowano bogactwo jej odniesień do zaświatów lub też do obszaru prywatnego pocieszenia indywidualnej duszy (ludzkiej). Jak przekonuje Latour w książce Nigdy nie bylismy nowocześni, upowszechnienie się przekonania o transcendentnej naturze Boga to „czwarta gwarancja Konstytucji Nowoczesności”. Być nowoczesnym to między innymi wiedzieć, że zarówno przyroda, jak i społeczeństwo to obiekty naturalne. Bóg nie objawia się w przyrodzie, natomiast umowy społeczne i konwencje kulturowe mają świeckie źródła. Nowoczesność usuwa Boga „z podwójnej konstrukcji natury i społeczeństwa”, czyniąc go zarazem sędzią bezsilnym, jak i absolutnie suwerennym (Latour 2011: 52-55).

Sprowadzając religijność w dobie modernizmu do domeny zawirowań serca pojedynczych ego, odebrano jej moc wpływu na bieg zdarzeń, utrącając szanse na jej przełożenie na praktykę. Duszę wyabstrahowano przy tym z ciała i kontekstu działań, izolując ją w kokonie subiektywnej i psychicznej duchowości. Brutalnie odcięta od usytuowanych praktyk zwykłych ludzi, religijność słabnie i zanika. W jednym z tekstów Latoura czytamy: „Nowoczesność zabrała bowiem religii jej energię, ograniczając ja, jak ujął to Whitehead, zaledwie do umeblowania duszy" (Latour 2009a: 28).

\footnotetext{
${ }^{4}$ Lech W. Zacher nazywa podobny sposób myślenia „imperatywem technicznym”. Zgodnie z tym imperatywem należy wykorzystać wszystkie możliwości techniki, ponieważ wypracowane w jej obrębie nowe rozwiązania uleczą wszelkie bolączki ludzkości: ekonomiczne, społeczne i ekologiczne (Zacher 2007: 171). Imperatyw techniczny przedstawia dalszą ekspansję nauki i techniki jako jedyną, właściwą i najlepszą reakcję na problemy generowane w obrębie tej właśnie dziedziny (i przemysłu).
} 
Książka francuskiego socjologa Jubiler - ou les Tourments de la Parole Religieuse (Latour 2002, por. Latour 1999, Bińczyk 2003) dyskutuje ewentualne warunki ożywienia dyskursu religijnego we współczesnych czasach, gdy obecność Boga oraz deklaracje wiary nie stanowia już powszechnej tkanki życia. Przede wszystkim, w opinii Latoura, religię należy traktować poważnie, czyli religijnie, zgodnie z jej własną logiką. Znaczy to, że nie wolno jej umieszczać w kontekstach z gruntu dla niej obcych, takich jak chociażby sfera polityki czy nauki. Zdaniem współtwórcy teorii aktora-sieci ożywienie religijne nie jest kwestia wymagająca nawrotu wiary - jest ono możliwe w obrębie przekazu o charakterze w pełni racjonalnym (stanowisko to jest zatem bliższe teologii naturalnej niźli objawionej) ${ }^{5}$. Co ciekawe, omawiana praca została napisana z pozycji otwarcie agnostycznych. Nawet ateizm mógłby stanowić doskonały punkt wyjścia do podjęcia tworzonego przez Latoura projektu (por. Latour 2002: 4-5, 80, 12).

Główna teza wspomnianej wyżej książki głosi, że należy wciąż na nowo dokonywać translacji oraz transformacji przekazu religijnego po to, aby w zmieniającej się rzeczywistości mógł zachowywać swój autentyczny sens. Trzeba go tłumaczyć i zdradzać na nowo (fr. traduire/trabir) (Latour 2002: 60). Przekaz wiary nie powinien być dogmatyzowany - to sprowadza go do roli artefaktu. Deformowanie przekazu, przekręcanie, wypaczanie i specyficzne udręczenia (fr. tourments) mowy religijnej stanowia jej istotę.

Dyskurs religijny nie podlega interpretacji symbolicznej, historycznej czy też naukowej, zracjonalizowanej. Sfera religijności zdecydowanie różni się też od obszaru sztuki. Mowa religijna nie przynosi przyjemności, nie zawiera informacji ani nie ma odniesienia. Nie zapewnia nam dostępu do odległej Transcendencji. Francuski socjolog stawia tezę, iż żywy dyskurs religijny dotyczy tak naprawdę transformacji samych interlokutorów (Latour 2002: 39). Mowa religijna przypomina słowa zakochanych, ich dziesiątki próśb i pytań wciąż od nowa „Czy mnie kochasz?”, które wytyczaja bliskość, lecz nie mają odniesienia i nie niosą informacji. W mowie zakochanych rekonfiguruja się podmiotowości osób, które mówią, i zakwita bliskość (Latour 2002: 81 i n.). Co istotne, te rodzaje praktyk mowy (religijna i miłości) rozgrywają się oraz konstytuują tylko w teraźniejszości. Nie należy delegować ich do czasów, które już minęły. Mowa religijna będzie żywa tylko wtedy, kiedy będzie aktualna. Dobra nowina musi być słyszalna

\footnotetext{
${ }^{5}$ Choć Latour nazywa siebie „,katolikiem z rodziny winiarzy z Burgundii” (Latour 2009a: 26), to jednak nie opowiada się na rzecz żadnej konkretnej religii (zajmując się samą formą wypowiedzi religijnych, warunkami żywej mowy religijnej). Gdy wykorzystuje przykłady i metafory zaczerpnięte z tradycji chrześcijańskiej, nie uzasadnia swego wyboru inaczej niż przez odwołanie do swojej (przygodnej) biografii.
} 
w naszych czasach, wypowiedziana znanymi nam słowami. Mowa ta przekształca nas w osoby religijne „tu” i „teraz”. Co szczególnie ważne, uniwersalność przekazu religijnego w ujęciu francuskiego socjologa nigdy nie jest dana, ale kreowana i postulowana. Uniwersalność zrodzona przez religię znajduje się ciagle przed nami jako budowanie sensu w jej praktykach mowy, które wymagają uważnego oraz wytrwałego podejmowania wciąż na nowo.

Jak wskazuje Latour, żywej religii udaje się dokonać radykalnej transformacji codzienności. Dzięki niej możemy poczuć się związani relacjami, co kreuje oraz utrzymuje bliskość (fr. le prochain). Odnawianie wciąż na nowo wymiaru bliskości w mowie religijnej nie jest łatwe. Wszak warunki wiarygodności i szczerości dyskursu religijnego uległy dogłębnemu rozmontowaniu we współczesnym świecie. Religia nie dotyczy zatem obcych nam zaświatów, które wyprowadziliśmy poza nasze życie. Tajemnica jej przetrwania to jej usytuowanie w „tu” i ,teraz”, w ramach praktyk zbiorowości, wciąż na nowo dla kolejnych epok i pokoleń. Żywa mowa religijna uobecnia i „odnawia oblicze Ziemi” każdego dnia, gdy tylko powiedzie się jej i spełni warunki bycia wiarygodną oraz szczera. Zarówno wcielenie (inkarnacja), jak i zmartwychwstanie to radykalne transformacje, które zbudowały bliskość. Ponieważ autentyczność mowy religijnej wymaga ciagłego odnawiania jej przekazu i translacji za translacja, to (paradoksalnie) nic nie jest mniej konserwatywne, mniej toporne, mniej zleżałe niż prawdziwa religijność.

Co ciekawe, domeny nauki i religii w ujęciu francuskiego filozofa są do siebie niezwykle podobne. Obie dziedziny konstytuują oraz podtrzymuja bliskość przez serie udanych translacji, w sieciach i łańcuchach referencji ${ }^{6}$. Pracując $w$ nurcie antropologii laboratorium i studiów nad nauką oraz technologią, Latour od dawna zwraca uwagę, że poznanie jakiegokolwiek przedmiotu nie jest możliwe bez dokonania szeregu mediacji po drodze, bez ustanawiania wiarygodnych połączeń (od sproblematyzowania zagadnienia badawczego, przez wyselekcjonowane próbki danych w odpowiednich pojemnikach, wykresy na urządzeniu pomiarowym, rozbudowaną tabelę, wzory, aż do tekstu naukowego). Wszędzie tutaj znajdujemy kaskady transformacji. W praktyce naukowej ponosimy wysokie koszty translacji (kosztuja pomiary, standaryzacja miar i wag, mapy, instrumenty, instytucje, wyprawy badawcze czy na przykład archiwa oraz banki danych). To właśnie na nich opiera się praktyczny sukces nauki oraz technologii. Translacje

\footnotetext{
${ }^{6} \mathrm{Na}$ temat idei krążącej referencji (ang. circulating reference) w nauce zob. Bińczyk 2007: 223-233, na temat uwarunkowań sukcesu praktycznego laboratoriów i technonauki zob. Bińczyk 2012: 155-166.
} 
i mediacje wystapić muszą zarówno w obrębie dyscyplin naukowych gwarantujaccych przewidywalność, jak i w praktykach żywej mowy religijnej.

\section{/// Ocalić Gaję i zbawić zbiorowość}

W 2011 roku Latour zdecydowanie podkreślał, że szczególnym wyzwaniem politycznym i epistemologicznym okazuje się dziś znalezienie udanego sposobu symbolicznego reprezentowania nieznanych wcześniej problemów globalnych, takich jak ocieplenie klimatu ${ }^{7}$. Wobec problemu zmiany klimatycznej wszyscy jesteśmy melancholijnymi sceptykami stwierdza autor Nadziei Pandory. Każdego dnia, nie podejmując działań zaradczych, zaprzeczamy realności procesów destabilizacji klimatu. Nasz sceptycyzm legitymizuje bierność. Tymczasem fakt globalnego ocieplenia, wywołanego emisjami gazów cieplarnianych i działalnością człowieka, pomimo kontrowersji w mediach publicznych, rozbudzanych przez osoby zaangażowane w zaprzeczanie globalnemu ociepleniu (ang. global warming denial), jest, zdaniem Latoura, jednym z najlepiej udokumentowanych faktów w historii nauki (Latour 2011a: 4) ${ }^{8}$.

Wiek XXI to wyjątkowy moment polityczny, sytuujący się u kresu czasu. Żyjemy w warunkach globalizacji, ale możemy narazić na szwank stabilność całego globu. Jak przedstawić tę niezwykłą sytuację? Solidarne zjednoczenie wobec problemów środowiskowych musi być dopiero wypracowane. Zbiorowość wymaga w tym względzie skomponowania (Latour

\footnotetext{
${ }^{7}$ Miało to miejsce podczas wykładu poświęconego figurom Gai i Atlasa na konferencji Science and Democracy (Latsis-Symposium), która odbyła się w Zurychu w Szwajcarii w dniach 26-28 maja 2011. Została ona zorganizowana przez Ludwik Fleck Zentrum at Collegium Helveticum, University of Zürich oraz ETH wZurychu.

${ }^{8}$ Latour powołuje się w tym miejscu przede wszystkim na następujące prace: Hamilton 2010, Hoggan, Littlemore 2009, Oreskes, Conway 2010, Edwards 2010. Warto zaznaczyć, że wspomniany tu ruch zaprzeczania globalnemu ociepleniu jest określany jako jeden z przykładów tak zwanego przemysłu wspierania produktów (ang. product defence industry) czy „produkowania na zlecenie wattpliwości i niewiedzy" (por. Michaels 2008, Proctor 1995). Chodzi o ekspertów, think tanki, instytuty, firmy konsultingowe i firmy public relations, które profesjonalnie zajmuja się wytwarzaniem atmosfery kontrowersyjności wokół ekspertyz mogących zaszkodzić pewnym aktorom (koncernom tytoniowym, paliwowym, biotechnologicznym). Jedna z lepiej udokumentowanych prac dotyczących produkcji wątpliwości na zlecenie, w tym także zjawiska podsycania sceptycyzmu wobec zmiany klimatycznej, to empiryczne studium Merchants of Doubt (Oreskes, Conway 2010). Bazuje ono na danych, które ujrzały światło dzienne dzięki upublicznieniu materiałów z procesów sądowych przeciwko przemysłowi tytoniowemu w USA w latach dziewięćdziesiątych XX wieku. Dokumenty ze wspomnianych procesów zostały opublikowane przez University of California, San Francisco jako Legacy Tobacco Documents Library. Są dostępne pod adresem http://legacy.library.ucsf.edu. Umożliwiły one ukazanie powiązań pomiędzy przemysłem tytoniowym i paliwowym oraz wybranymi instytutami naukowymi lub też think tankami. Dokumenty te zawierają m.in. podręczniki instruujące, w jaki sposób kreować wattpliwości i kontrowersyjność danych tez, a nawet listy ekspertów gotowych służyć jako komentatorzy na zlecenie, we wskazany sposób. Temat ten rozwijam gdzie indziej (Bińczyk 2013).
} 
2011a). Niestety, nie wiadomo, na jakiej zasadzie ludzkość mogłaby tego dokonać. Nigdy nie staliśmy przed podobna koniecznością. Możliwość nieodwracalnej destabilizacji środowiska winna skłonić do działania, zmotywować do decyzji politycznych. W takiej sytuacji jednak sama polityka musi być inaczej rozumiana. Przede wszystkim w społeczeństwie ryzyka, kontrowersji i globalnych, heterogenicznych zależności musimy umieć działać politycznie, nie mając komfortu absolutnej pewności.

Zdaniem francuskiego socjologa pomocna może się okazać figura Atlasa, który trzyma Ziemię na swych barkach. Sytuacja ludzkości wobec problemu zmiany klimatycznej przypomina położenie Atlasa. Jesteśmy uwikłani w problemy ekologiczne na Ziemi, ale równocześnie przyszłość planety leży w naszych rękach. Wiemy, że jest ona zależna od decyzji politycznych i ekonomicznych podejmowanych właśnie dzisiaj. Przyszła postać klimatu znajduje się nawet w zasięgu działań zwykłych ludzi, chociaż trudno uznać, że ktokolwiek z nas ponosi dobrze określoną odpowiedzialność. Postnaturalne przekleństwo Atlasa polega na tym, że nie mamy żadnych innych wolnych planet do wykorzystania. Jesteśmy zaskoczeni tą sytuacją, a także zupełnie bezradni. W swych wykładach Facing Gaia Latour zauważa, że wobec poprzednich zagrożen, takich jak na przykład groźba ataku podczas zimnej wojny, społeczeństwa zachodnie potrafily reagować błyskawicznie, zbrojąc się natychmiast, chociaż sama możliwość takiego wydarzenia nie była dobrze udokumentowana. W obliczu problemu zmiany klimatycznej ciagle nie zrobiono prawie nic ${ }^{9}$.

W opinii Latoura w wypadku rozpoznania i przeciwdziałania takiemu zagrożeniu, jakim jest destabilizacja klimatu, stoi przed nami wyzwanie skali. Potrzebujemy centrum kalkulacji (i koordynacji) zdolnego objać swym zasięgiem całą ludzkość, cała planetę, przyszłość zbiorowości. Potrzebujemy instytucji oraz instrumentów naukowych prezentujących globalne zagrożenia środowiskowe wyobraźni publicznej. Zbiorowość musi być coraz lepiej informowana, aby mogła stać się też bardziej wrażliwa. To właśnie sieci referencji w praktyce badawczej nauk ścisłych podnoszą naszą wrażliwość na problemy środowiska. Dzięki nim możemy odczuć istotę i zakres wyzwań antropocenu. Zmiana klimatyczna to problem z konieczności wywodzący się z lokalnych danych, bowiem nigdy stan planety nie pozwala

\footnotetext{
${ }^{9}$ Unia Europejska dysponuje Europejskim Systemem Handlu Emisjami (European Trading Scheme, ETS). Polega on na ustaleniu limitów emisji dwutlenku węgla, a następnie na wydawaniu pozwoleń na emisję poszczególnym aktorom. Niewykorzystane limity emisji mogą następnie być odsprzedawane. Zaznaczmy jednak, iż handel emisjami to zaledwie zarys rynku, wymagający uregulowań oraz znaczących reform. Zmaga się on na przykład z problemem pozornego redukowania emisji zanieczyszczeń, bowiem poziom redukcji przewidywanej emisji trudno jest ocenić, jak również kontrolować.
} 
nam się mierzyć bezpośrednio. Globalna skala problemu ocieplenia klimatu musiała zostać wykazana w szeregu naukowych wysiłków translacji i mediacji. Znalazła się $\mathrm{w}$ naszym zasięgu dzięki technikom obecnym w nauce, instrumentom służącym osiaganiu współmierności, czujnikom, procesom standaryzacji, sieciom stacji pomiaru, powtarzanym wciąż od nowa zabiegom rekalibrowania danych przez modele oraz transformacji modeli w konfrontacji z osiaganymi sekwencjami danych ${ }^{10}$.

Wedle Latoura ciagle nie dysponujemy jednak jasnym obrazem podstaw globalnej solidarności, która w kontekście problemu destabilizacji klimatu okazuje się nieodzowna. Nie wiemy jeszcze z góry, jakie czynniki są naszymi sprzymierzeńcami, a jakie wrogami. Tak samo jak rozpoznanie problemu globalnego ocieplenia dokonuje się stopniowo, dzięki lokalnym infrastrukturom naukowym, podobnie globalna odpowiedzialność musi być wypracowana krok po kroku, dzięki wykorzystaniu sieci pośredników, zabiegów translacji i przekształceń. Przyszłe „my” ekologicznej odpowiedzialności zbiorowej jest i będzie jedynie prowizoryczne.

Ważna propozycja w ekoteologicznym projekcie Latoura jest wykorzystanie sekularnej metafory czy też kategorii Gai (zamiast takich alternatyw, jak „Natura”, „System”, „Glob”). Gaja, o której mówi Latour, różni się wyraźnie od Natury - kategorialnego wytworu modernizmu, niemej instancji rządzonej obiektywnymi prawami, w której imieniu wypowiadali się eksperci nauk ścisłych. Gaja nie stanowi też cybernetycznego Systemu przewidywalnych relacji i powiązań, które łatwo moglibyśmy poddać kontroli. Wyobrażenie Globu (ang. globe) - doskonałej, symetrycznej kuli ziemskiej, również nie oddaje naszej sytuacji, w nieuprawniony sposób sugeruje bowiem kompletność i komplementarność, którymi jeszcze nie dysponujemy. Gaja nie jest również jakimś superorganizmem, nie należy jej pojmować jako byt zunifikowany ontologicznie (Latour 2011a: 10).

Stanowiąc mozaikę zależności, Gaja jest raczej lokalna niż uniwersalna (Latour 2011a: 8-9). Konstytuują ją wzajemne splątania różnorodnych oddziaływań, ośrodków sprawczości (ang. multiple agencies). Mamy do czynienia z relacjami o charakterze heterogenicznym: to, co materialne, naturalne, polityczne $\mathrm{i}$ techniczne, narracje $\mathrm{i}$ instytucje tworza gęsty galimatias zależności. Musimy dopiero go poznać. Nic nie jest dane z góry. To szereg nakładających się na siebie pętli oddziaływań, które nie tworzą harmonii ani homeostazy jednorodnego systemu. Pętle oddziaływań moga

\footnotetext{
${ }^{10}$ Latour powołuje się w tym miejscu na pracę ukazującą detale komponowania w obrębie nauk klimatycznych spójnego obrazu problemu ocieplenia klimatu. Nosi ona tytuł A Vast Macbine: Computer Models, Climate Data, and the Politics of Global Warming (Infrastructures) (Edwards 2010).
} 
także przynieść niespodziewane rezultaty. Gaja jest bowiem (paradoksalnie) superwrażliwa wobec naszych ingerencji, a zarazem obojętna. Jak pokazał James Lovelock, który pod koniec lat siedemdziesiątych XX wieku wraz z biolożką Lynn Margulis sformułował „hipotezę Gai” - równowaga planety nie zależy wcale od tego, czy gatunek ludzki wyginie. Ona przetrwa, to raczej ludzkość znajduje się w sytuacji zagrożenia.

W dynamicznych procesach odtwarzania Gai, owej plątaniny relacji i powiązań, każdy owad, mikrob i organizm narażony jest na wiele form ryzyka. Szereg aktorów podejmuje wysiłki zawłaszczania terytorium oraz reprodukcji. Podtrzymuja oni swoje życie, utrwalaja je i stabilizuja. Sa to uwikłane w różnorodne zależności miliony ośrodków sprawczości, wrażliwych na swe otoczenia (niem. Umwelt), bez odgórnych planów, bez optimum, bez żadnej zewnętrznej Przyczyny Celowej. Esencjalistyczny model danych z góry bytów, trwałych istot, rzeczy jako res extensa, nie jest w stanie odzwierciedlić tego typu dynamiki ${ }^{11}$.

W tym momencie możemy wrócić już do zagadnienia religijności. Jak twierdzi współtwórca teorii aktora-sieci, łańcuch bytów stanowiących Gaję nie jest dany z góry i nie rządzi się odgórną stabilnością czy zespołem praw, które pozwoliłyby nam spać spokojnie. Gaja jest niezwykle wrażliwa i natychmiast reaguje na najmniejsze interwencje. Podobna logika żywiołowości i nieprzewidywalności dotyczy autentycznej mowy religijnej. Religia, która każdego dnia zdolna jest „odnawiać oblicze Ziemi”, jest tak samo dynamiczna w swych translacjach, przekręceniach oraz wypaczeniach mowy. Przekaz religijny jest jak dynamika Gai, narażony i wrażliwy wobec każdej nowej propozycji. Na dynamizm ten musimy stać się czuli, projektując planetarną solidarność i odpowiedzialność.

Czy zbiorowość zostanie zbawiona, a Gaja ocalona? Co nas czeka w opinii Latoura? Jak odpowiedział podczas dyskusji w ramach Gifford Lectures: przyszłość zbiorowości to najpewniej wypadkowa adaptacji, łagodzenia skutków klimatycznej destabilizacji i cierpienia.

\footnotetext{
${ }^{11} \mathrm{~W}$ jednym z polskich opracowań na temat genetyki znajdujemy bardzo podobne ujęcie procesów biologicznych: „Jeśli ktoś domaga się od nas, biologów, sformułowania filozofii życia, proszę, oto ona: brak idealnych wzorców, nieograniczona różnorodność form i rozmaite rozwiązania tych samych problemów, oportunizm, działanie ad hoc, majsterkowanie, czyli wykorzystywanie tego, co jest pod ręka, trwanie za wszelką cenę i zasada indywidualnej korzyści” (Jerzmanowski 2001: 188). (Dziękuję dr Aleksandrze Derra z IF UMK za zwrócenie uwagi na powyższy cytat.)
} 
Bibliografia:

/// Bińczyk E. 2003. Bez tytutu, „Przegląd Religioznawczy” 2003, nr 1, s. 175-180 (rec. Latour B. 2002. Jubiler - ou les Tourments de la Parole Religieuse, Les Empêcheurs de Penser en Rond, Paryż).

/// Bińczyk E. 2007. Obraz, który nas zniewala. Wspótczesne ujecia jezylka wobec esencjalizmu i problemu referencji, Universitas, Kraków.

/// Bińczyk E. 2012. Technonauka w spoteczeństwie ryzyka. Filozofia wobec niepożadanych nastepstw praktycznego sukcesu nauki, Wydawnictwo Naukowe UMK, Toruń.

/// Bińczyk E. 2013. Problem sceptycyzmu wobec zmiany klimatycznej a (post)konstruktywizm, „Przegląd Kulturoznawczy” 2013, nr 1(15).

/// Crutzen P.J., Stoermer E.F. 2000. The 'Anthropocene'. „Global Change Newsletter" 2000, nr 41, s. 17-18.

/// Edwards P.N. 2010. A Vast Machine: Computer Models, Climate Data, and the Politics of Global Warming (Infrastructures), The MIT Press, Cambridge, MA, London.

/// Hamilton C. 2010. Requiem for A Species. Why We Resist the Truth About Climate Change, Earthscan, London, Washington.

/// Hoggan J., Littlemore R. 2009. Climate Cover-Up: the Crusade to Deny Global Warming, Greystone Books, Vancouver.

/// Jerzmanowski A. 2001. Geny i życie. Niepokoje wspótczesnego biologa, Wydawnictwo Prószyński i S-ka, Warszawa.

/// Kiepas A. 2000. Cztowiek wobec dylematón filozofii techniki, Wydawnictwo Gnome, Katowice.

// / Latour B. 1999. "Thou shalt not take the Lord's name in vain « — being a sort of sermon on the hesitations of religious speech. „Res” 1999, $\mathrm{nr}$ 39, s. 215-234; http://www.bruno-latour.fr/sites/default/files/79-RES-SERMON-GB. pdf; dostęp: 3.03.2013.

/// Latour B. 2002. Jubiler - ou les Tourments de la Parole Religieuse, Les Empêcheurs de Penser en Rond, Paryż.

/// Latour B. 2003. The Promises of Constructivism, [w:] Chasing Technoscience. Matrix for Materiality, D. Ihde, E. Selinger (red.), Indiana University Press, Bloomington, Indianapolis, s. 27-46. 
/// Latour B. 2009. Polityka natury. Nauki wkraczaja do demokracji, tłum. A. Czarnacka, Wydawnictwo Krytyki Politycznej, Warszawa.

/// Latour B. 2009a. Cay nie-ludzie zostana ₹bawieni? Argument ekoteologiczny, tłum. M. Bokiniec, [w:] Ekologia. Przewodnik krytyki politycznej, Wydawnictwo Krytyki Politycznej, Warszawa, s. 18-52.

/// Latour B. 2011. Nigdy nie bylismy nowocześni. Studium z antropologii symetrycznej, tłum. M. Gdula, Oficyna Naukowa, Warszawa.

/// Latour B. 2011a. Waiting for Gaia. Composing the Common World through Arts and Politics, wykład w the French Institute, Londyn, listopad 2011, http.: / www.bruno-latour.fr/node/446; dostęp: 5.03.2013.

/// Latour B. 2012. Nadrieja Pandory. Eseje o rzecsynistości w studiach nad nauka, red. nauk. K. Abriszewski, Wydawnictwo Naukowe UMK, Toruń.

/// Latour B. 2013. Facing Gaia. A New Inquiry into Natural Religion, The University of Edinburgh Gifford Lectures, dostępne na żywo w sieci: 1828.02.2013, http://www.ed.ac.uk/schools-departments/humanities-socsci/news-events/lectures/gifford-lectures/series-2012-2013.

/// Michaels D. 2008. Doubt is Their Product. How Industry's Assault on Science Threatens Your Health, Oxford University Press, Oxford.

/// Oreskes N., Conway E. 2010. Merchants of Doubt: How a Handful of Scientists Obscured the Truth o Issues from Tobacco Smoke to Global Warming, Bloomsbury Press, New York.

/// Proctor R.N. 1995. Cancer Wars: How Politics Shapes What We Know and Don't Know about Cancer, Basic Books, New York.

/// Zacher L.W. 2007. Transformacje spoteczeństw: od informaci do wiedsy, Wydawnictwo C.H. Beck, Warszawa.

\section{/// Abstrakt}

Artykuł prezentuje ekoteologiczne sugestie francuskiego socjologa, współtwórcy teorii aktora-sieci (ANT), Brunona Latoura. Omówiona zostaje postsekularna koncepcja żywej mowy religijnej Latoura (wymagającej szeregu translacji konstytuujących bliskość w interlokutorach). Tekst wskazuje korzyści płynące z zastosowania metafor Atlasa oraz Gai w kontekście politycznego problemu braku solidarnej reakcji zbiorowości na problem globalnego ocieplenia. 
Słowa kluczowe:

teoria aktora-sieci, teologia polityczna, polityka natury, zbiorowość, czynniki pozaludzkie, Gaja

\section{/// Abstract}

The article presents selected ecotheological suggestions of Bruno Latour (French sociologist who created the so-called Actor-Network Theory). Latour's postsecular model of the authentic religious speech is also described (this kind of speech can be produced by a series of translations that constitute proximity between interlocutors). The text indicates important advantages of such metaphors as „Atlas” and „Gaia”. They could play a crucial role in coping with the political problem of the lack of any united collective reaction towards the threat of global warming.

Key words:

Actor-Network Theory, political theology, politics of nature, collective, non-humans, Gaia 